\title{
Management of Iron and Aluminium Toxicity in Acid Sulphate Soils of Kuttanad
}

\author{
N.L. Ebimol*, P.R. Suresh, N.K. Binitha and G.R. Santhi \\ College of Agriculture, Kerala Agricultural University, Padannakkad, Kasaragod- 671314, \\ Kerala, India \\ *Corresponding author
}

\section{A B S T R A C T}

\section{Keywords}

Iron and aluminium toxicity, Acid sulphate soil.

Article Info

Accepted:

12 September 2017

Available Online:

10 November 2017
An incubation experiment was carried out at College of Agriculture, Padannakkad during 2015-2017 to examine suitable amelioration strategies for the iron and aluminium toxicity in acid sulphate soils of Kuttanad. The acid sulphate soils of Kuttanad region are having extreme soil $\mathrm{pH}$ and toxicity of Fe and $\mathrm{Al}$ can be ameliorated using amendments and hence can be made more productive. During the submergence period among the various parameters monitored, a steady increase was observed for $\mathrm{pH}, \mathrm{Ca}$ and $\mathrm{Mg}$ of the soil. Application of phosphogypsum $+1 / 2$ lime $\left(T_{2}\right)$ showed the highest increase in soil $\mathrm{pH}$ and available calcium content and was highly effective in lowering the toxic concentration of $\mathrm{Fe}$ and $\mathrm{Al}$ in the acid sulphate soils of Kuttanad.

\section{Introduction}

Kuttanad of Alleppey district, the rice bowl of Kerala is a unique agricultural tract lying 0.6 to $2.2 \mathrm{~m}$ below the mean sea level on the west coast of India. It has a geographic area of 0.85 lakh ha. This comprised of 50,000 ha of rice fields, out of which 14,227 ha belongs to acid sulphate soils (typicsulfaquent) known as the kari lands which is the most problematic area of rice cultivation. Several parts of this area have subsoil layers containing pyrites which on drainage and oxidation produce severe acidity.

Iron toxicity commonly occurs in a wide range of acid soils, particularly in lowland rice with permanent flooding. Excess concentration of reduced iron $\left(\mathrm{Fe}^{2+}\right)$ results in a range of nutrient disorders and results in deficiencies of other major and micro nutrients. Aluminum toxicity is also one of the major concerns of low rice productivity in lowland acid sulfate soils (Fageria and Carvalho, 1982). Aluminum toxicity affects about $40-70 \%$ of the world's arable land, which has the potential for food crop and biomass production. Aluminium toxicity impairs productivity in soils having low $\mathrm{pH}$ (below 5.0).

The occurrence of metal toxicity predominantly of iron and aluminium in many cases can be overcome by the addition of lime 
(calcium carbonate), or slaked lime (calcium hydroxide), magnesium carbonate or other alkaline/liming materials to increase the soil $\mathrm{pH}$ and precipitate the toxic metals and thus increase plant growth. Phosphorus deficiency is another problem in these areas.

This is because of the high $\mathrm{P}$ fixation capacity of the soil due to the occurrence of high concentration of iron and aluminium. Availability of phosphorous is decreased in extreme acidic condition (Suswanto et al., 2007).

Since the acid sulphate soils of Kuttanad is an important problematic area with extreme acidity, toxicity of iron, aluminium coupled with deficiency of phosphorous, application of different amendments and other nutrients should be used for successful cultivation in these area.

\section{Materials and Methods}

An incubation experiment was conducted using the soil sample collected from 'Kari' lands of Kuttanad at College of Agriculture, Padannakkad as a preliminary study prior to the pot culture experiment. The study was conducted using four different treatments at two levels of submergence $(5 \mathrm{~cm}$ and $10 \mathrm{~cm})$. The treatments were designed based on the recommendations of KAU POP 2011 viz. lime $\left(\mathrm{T}_{1}\right)$; phosphogypsum $+1 / 2$ lime $\left(\mathrm{T}_{2}\right)$; magnesium carbonate $+1 / 2$ lime $\left(\mathrm{T}_{3}\right)$ and control $\left(\mathrm{T}_{4}\right)$. The treatments were applied in factorial combination and the design was CRD.

The treatments were incorporated kept under submergence. The analysis of various parameters was done at 30,60 and 90 days after submergence. The samples were analyzed for $\mathrm{pH}$, available nutrients such as $\mathrm{Ca}, \mathrm{Mg}, \mathrm{Fe}$ and $\mathrm{Al}$ as per the standard procedures.

\section{Results and Discussion}

The results of the incubation study showed that the treatments had significant effect on soil $\mathrm{pH}$, available calcium, magnesium, iron and aluminium throughout the submergence period.

Soil $\mathrm{pH}$ was found to be increasing during the course of incubation study. The level of submergence at $5 \mathrm{~cm}$ and $10 \mathrm{~cm}$ and the interaction between treatments and levels of submergence were non-significant whereas application of different amendments showed significance (Table 1). At 30 days after incubation application of lime $\mathrm{T}_{1}$ (@500 kgha ${ }^{-}$ $\left.{ }^{1}\right)$ showed maximum increase (5.85) in $\mathrm{pH}$. This may be due to the ability of lime to neutralize the $\mathrm{pH}$. After 60 and 90 days of submergence $\quad(5.81, \quad 6.61$ respectively) phosphogypsum @ $500 \mathrm{kgha}^{-1}+1 / 2$ lime (as per KAU POP) showed dominance in $\mathrm{pH}$ which might be attributed to the higher amount of $\mathrm{Ca}$ present in the treatment receiving combination of phosphogypsum and lime. Both phosphogypsum and lime are highly effective amendments in reducing the soil acidity on submerged condition. Similar results of lime and phophogypsum in increasing the soil $\mathrm{pH}$ were reported by Lee et al., (2007), Suswanto et al., (2007) and Shamshuddin et al., (2015).

The available Ca was found to increase during the period of incubation. The treatments showed significant effect throughout the incubation period. The levels of submergence and interaction between levels of submergence and treatments were non-significant with respect to availability of $\mathrm{Ca}$. Application of phosphogypsum $+1 / 2$ lime $\left(\mathrm{T}_{2}\right)$ showed significantly superior available Ca after 30, 60 and 90 days of incubation(475, 551, 653 respectively). It may be because of the higher availability of $\mathrm{Ca}$ applied through phosphogypsum and enhanced $\mathrm{pH}$ due to lime (Table 2). 
Table.1 Changes in $\mathrm{pH}$ of soil incorporated with different amendments

\begin{tabular}{|c|c|c|c|c|c|c|c|c|c|}
\hline \multirow[b]{2}{*}{ Treatments } & \multicolumn{3}{|c|}{ pH 30 days after incubation } & \multicolumn{3}{|c|}{ pH 60 days after incubation } & \multicolumn{3}{|c|}{ pH 90 days after incubation } \\
\hline & $\mathrm{L}_{1}$ & $\mathrm{~L}_{2}$ & Mean & $\mathrm{L}_{1}$ & $\mathrm{~L}_{2}$ & Mean & $\mathrm{L}_{1}$ & $\mathrm{~L}_{2}$ & Mean \\
\hline $\mathrm{T}_{1}$ & 5.75 & 5.94 & 5.85 & 5.79 & 5.79 & 5.79 & 6.25 & 6.43 & 6.34 \\
\hline $\mathrm{T}_{2}$ & 5.74 & 5.32 & 5.53 & 5.84 & 5.81 & 5.82 & 6.52 & 6.71 & 6.61 \\
\hline $\mathrm{T}_{3}$ & 5.26 & 4.79 & 5.03 & 5.15 & 5.28 & 5.22 & 6.23 & 6.12 & 6.17 \\
\hline $\mathrm{T}_{4}$ & 3.57 & 3.48 & 3.53 & 4.25 & 4.49 & 4.37 & 5.51 & 5.81 & 5.66 \\
\hline Mean & 5.08 & 4.88 & & 5.26 & 5.34 & & 6.13 & 6.27 & \\
\hline Comparison & SE(m) & \multicolumn{2}{|c|}{ CD (5\%) } & SE(m) & \multicolumn{2}{|c|}{ CD $(5 \%)$} & $\mathrm{SE}(\mathrm{m})$ & \multicolumn{2}{|c|}{ CD $(5 \%)$} \\
\hline $\mathrm{L}$ & 0.095 & \multicolumn{2}{|c|}{ NS } & 0.16 & \multicolumn{2}{|c|}{ NS } & 0.096 & \multicolumn{2}{|c|}{ NS } \\
\hline $\mathrm{T}$ & 0.14 & \multicolumn{2}{|c|}{0.41} & 0.23 & \multicolumn{2}{|c|}{0.69} & 0.14 & \multicolumn{2}{|c|}{0.41} \\
\hline Lx T & 0.19 & \multicolumn{2}{|c|}{ NS } & 0.32 & \multicolumn{2}{|c|}{ NS } & 0.19 & \multicolumn{2}{|c|}{ NS } \\
\hline
\end{tabular}

Table.2 Changes in available $\mathrm{Ca}\left(\mathrm{mg} \mathrm{kg}^{-1}\right)$ of soil incorporated with different amendments

\begin{tabular}{|c|c|c|c|c|c|c|c|c|c|}
\hline \multirow{2}{*}{ Treatments } & \multicolumn{3}{|c|}{ Ca 30days after incubation } & \multicolumn{3}{|c|}{ Ca 60days after incubation } & \multicolumn{3}{|c|}{ Ca 90days after incubation } \\
\hline & $\mathrm{L}_{1}$ & $\mathrm{~L}_{2}$ & Mean & $\mathrm{L}_{1}$ & $\mathrm{~L}_{2}$ & Mean & $\mathrm{L}_{1}$ & $\mathrm{~L}_{2}$ & Mean \\
\hline $\mathrm{T}_{1}$ & 342.50 & 344.58 & 343.54 & 526.70 & 529.98 & 528.34 & 553.97 & 599.38 & 576.67 \\
\hline $\mathrm{T}_{2}$ & 478.17 & 472.50 & 475.33 & 536.50 & 551.23 & 543.87 & 617.30 & 690.63 & 653.97 \\
\hline $\mathrm{T}_{3}$ & 343.75 & 364.58 & 354.17 & 492.48 & 493.32 & 492.90 & 521.88 & 532.72 & 527.30 \\
\hline $\mathrm{T}_{4}$ & 311.50 & 334.42 & 322.96 & 392.90 & 394.05 & 393.47 & 378.97 & 381.88 & 380.43 \\
\hline Mean & 368.98 & 379.02 & & 487.15 & 492.15 & & 518.03 & 551.15 & \\
\hline Comparison & $\mathrm{SE}(\mathbf{m})$ & \multicolumn{2}{|c|}{ CD $(5 \%)$} & SE(m) & \multicolumn{2}{|c|}{ CD $(5 \%)$} & $\mathrm{SE}(\mathrm{m})$ & \multicolumn{2}{|c|}{ CD $(5 \%)$} \\
\hline $\mathrm{L}$ & 13.12 & \multicolumn{2}{|c|}{ NS } & 18.46 & \multicolumn{2}{|c|}{ NS } & 29.45 & \multicolumn{2}{|c|}{ NS } \\
\hline $\mathrm{T}$ & 18.56 & \multicolumn{2}{|c|}{56.12} & 26.11 & \multicolumn{2}{|c|}{78.96} & 41.65 & \multicolumn{2}{|c|}{125.93} \\
\hline $\mathrm{Lx} \mathrm{T}$ & 26.24 & \multicolumn{2}{|c|}{ NS } & 36.93 & \multicolumn{2}{|c|}{ NS } & 58.89 & \multicolumn{2}{|c|}{ NS } \\
\hline
\end{tabular}


Table.3 Changes in available $\mathrm{Mg}\left(\mathrm{mg} \mathrm{kg}^{-1}\right)$ of soil incorporated with different amendments

\begin{tabular}{|c|c|c|c|c|c|c|c|c|c|}
\hline \multirow[b]{2}{*}{ Treatments } & \multicolumn{3}{|c|}{ Mg 30days after incubation } & \multicolumn{3}{|c|}{ Mg 60days after incubation } & \multicolumn{3}{|c|}{ Mg 90days after incubation } \\
\hline & $\mathrm{L}_{1}$ & $\mathrm{~L}_{2}$ & Mean & $\mathrm{L}_{1}$ & $\mathrm{~L}_{2}$ & Mean & $\mathrm{L}_{1}$ & $\mathrm{~L}_{2}$ & Mean \\
\hline $\mathrm{T}_{1}$ & 55.50 & 58.00 & 56.75 & 57.30 & 55.10 & 56.20 & 52.73 & 53.17 & 52.95 \\
\hline $\mathrm{T}_{2}$ & 69.17 & 64.87 & 67.02 & 62.07 & 58.80 & 60.43 & 64.83 & 62.67 & 63.75 \\
\hline $\mathrm{T}_{3}$ & 79.33 & 71.48 & 75.41 & 89.367 & 89.00 & 89.18 & 82.33 & 83.33 & 82.83 \\
\hline $\mathrm{T}_{4}$ & 38.13 & 37.33 & 37.73 & 43.40 & 35.97 & 39.68 & 33.83 & 33.67 & 33.75 \\
\hline Mean & 60.53 & 57.92 & & 63.03 & 59.72 & & 58.43 & 58.21 & \\
\hline Comparison & SE(m) & \multicolumn{2}{|c|}{ CD (5\%) } & SE(m) & \multicolumn{2}{|c|}{ CD (5\%) } & SE(m) & \multicolumn{2}{|c|}{ CD (5\%) } \\
\hline $\mathrm{L}$ & 1.452 & \multicolumn{2}{|c|}{ NS } & 2.28 & \multicolumn{2}{|c|}{ NS } & 1.30 & \multicolumn{2}{|c|}{ NS } \\
\hline $\mathrm{T}$ & 2.054 & \multicolumn{2}{|c|}{6.21} & 3.23 & \multicolumn{2}{|c|}{9.76} & 1.84 & \multicolumn{2}{|c|}{5.56} \\
\hline $\mathrm{Lx} \mathrm{T}$ & 2.904 & \multicolumn{2}{|c|}{ NS } & 4.56 & \multicolumn{2}{|c|}{ NS } & 2.60 & \multicolumn{2}{|c|}{ NS } \\
\hline
\end{tabular}

Table.4 Changes in available Fe $\left(\mathrm{mg} \mathrm{kg}^{-1}\right)$ of soil incorporated with different amendments

\begin{tabular}{|c|c|c|c|c|c|c|c|c|c|}
\hline \multirow[t]{2}{*}{ Treatments } & \multicolumn{3}{|c|}{ Fe 30days after incubation } & \multicolumn{3}{|c|}{ Fe 60days after incubation } & \multicolumn{3}{|c|}{ Fe 90days after incubation } \\
\hline & $\mathrm{L}_{1}$ & $\mathrm{~L}_{2}$ & Mean & $\mathrm{L}_{1}$ & $\mathrm{~L}_{2}$ & Mean & $\mathrm{L}_{1}$ & $\mathrm{~L}_{2}$ & Mean \\
\hline $\mathrm{T}_{1}$ & 369 & 325 & 347 & 266 & 294 & 280 & 161 & 160 & 161 \\
\hline $\mathrm{T}_{2}$ & 312 & 321 & 316 & 244 & 277 & 260 & 158 & 161 & 159 \\
\hline $\mathrm{T}_{3}$ & 456 & 426 & 441 & 463 & 378 & 421 & 294 & 295 & 294 \\
\hline $\mathrm{T}_{4}$ & 543 & 529 & 536 & 551 & 581 & 566 & 366 & 390 & 378 \\
\hline Mean & 420 & 400 & & 381 & 382 & & 245 & 251 & \\
\hline Comparison & SE(m) & \multicolumn{2}{|c|}{$\operatorname{CD}(5 \%)$} & $\mathbf{S E}(\mathbf{m})$ & \multicolumn{2}{|c|}{$\mathrm{CD}(5 \%)$} & $\mathbf{S E}(\mathbf{m})$ & \multicolumn{2}{|c|}{$\mathrm{CD}(5 \%)$} \\
\hline $\mathrm{L}$ & 12.6 & \multicolumn{2}{|c|}{ NS } & 23.58 & \multicolumn{2}{|c|}{ NS } & 40.57 & \multicolumn{2}{|c|}{ NS } \\
\hline $\mathrm{T}$ & 17.9 & \multicolumn{2}{|c|}{54.19} & 33.34 & \multicolumn{2}{|c|}{100.83} & 57.38 & \multicolumn{2}{|c|}{173.50} \\
\hline Lx T & 25.34 & \multicolumn{2}{|c|}{ NS } & 47.16 & \multicolumn{2}{|c|}{ NS } & 81.14 & \multicolumn{2}{|c|}{ NS } \\
\hline
\end{tabular}


Table.5 Changes in $\mathrm{Al}\left(\mathrm{mg} \mathrm{kg}^{-1}\right)$ of soil incorporated with different amendments

\begin{tabular}{|c|c|c|c|c|c|c|c|c|c|}
\hline \multirow{2}{*}{ Treatments } & \multicolumn{3}{|c|}{ Al 30days after incubation } & \multicolumn{3}{|c|}{ Al 60days after incubation } & \multicolumn{3}{|c|}{ Al 90days after incubation } \\
\hline & $\mathrm{L}_{1}$ & $\mathrm{~L}_{2}$ & Mean & $\mathrm{L}_{1}$ & $\mathrm{~L}_{2}$ & Mean & $\mathrm{L}_{1}$ & $\mathrm{~L}_{2}$ & Mean \\
\hline $\mathrm{T}_{1}$ & 157.83 & 151.43 & 154.63 & 168.37 & 133.77 & 151.07 & 162.43 & 160.73 & 161.58 \\
\hline $\mathrm{T}_{2}$ & 145.97 & 142.47 & 144.22 & 132.20 & 127.84 & 130.02 & 103.93 & 106.76 & 105.35 \\
\hline $\mathrm{T}_{3}$ & 255.30 & 246.31 & 250.81 & 231.60 & 158.82 & 195.21 & 198.93 & 179.63 & 189.28 \\
\hline $\mathrm{T}_{4}$ & 326.40 & 298.87 & 312.63 & 316.10 & 314.83 & 315.46 & 236.70 & 225.83 & 231.26 \\
\hline Mean & 221.38 & 209.77 & & 212.07 & 183.82 & & 175.50 & 168.24 & \\
\hline Comparison & SE(m) & CD & $\%)$ & SE(m) & CD & & $\mathbf{S E}(\mathbf{m})$ & CD & \\
\hline $\mathrm{L}$ & 20.07 & & & 30.03 & & & 18.72 & & \\
\hline $\mathrm{T}$ & 28.38 & & & 42.47 & & & 26.47 & & \\
\hline Lx T & 40.14 & & & 60.06 & & & 37.45 & & \\
\hline
\end{tabular}


Fig.1 $\mathrm{pH}$ as influenced by treatments in the incubation experiment

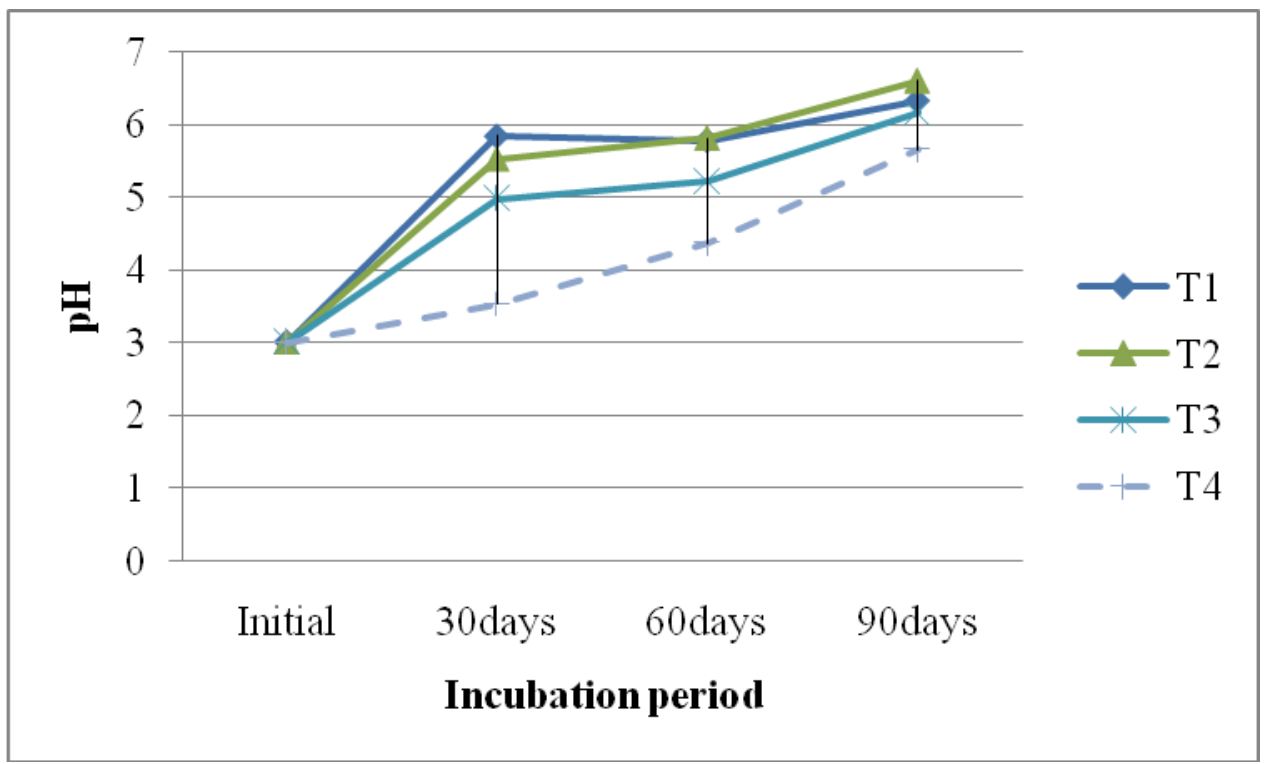

Fig.2 $\mathrm{Ca}$ as influenced by treatments in the incubation experiment

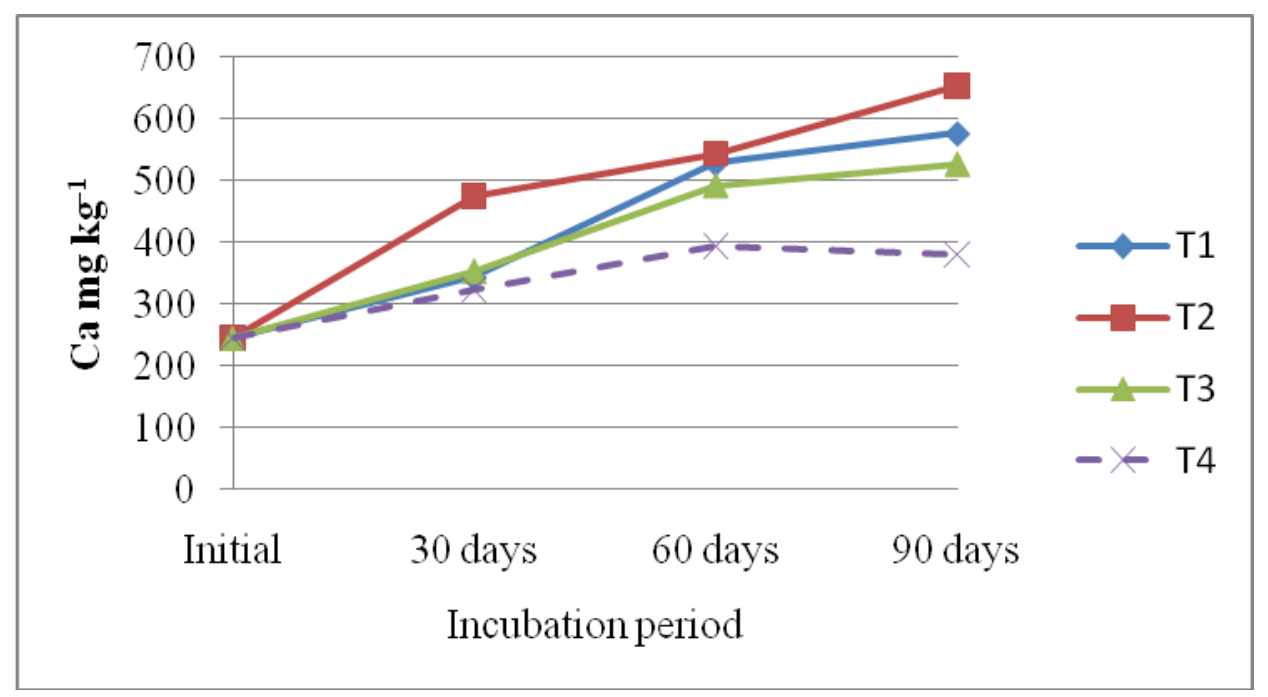

Moreover calcium present in phosphogypsum is readily soluble form and thereby enhancing its availability in soil (Deepa, 2008; Lee et al., 2006; Azman et al., 2013).

The treatments were highly significant with respect to availability of $\mathrm{Mg}$ whereas the levels of submergence and interaction between levels of submergence and treatments were found to be non-significant. The application of magnesium carbonate $+1 / 2$ lime $\left(T_{3}\right)$ was recorded as the superior treatment with regard to available $\mathrm{Mg}$. This may be because of the availability of $\mathrm{Mg}$ through the treatment. Suswanto et al., (2007), Shamshuddin et al., (2015) and Castro et al., (2016) also reported that application of ground magnesium limestone containing $\mathrm{Mg}$ 
increased the availability of magnesium. Iron and aluminium concentration in the soil showed a decreasing trend throughout the incubation period. The treatments showed significant effect in reducing the toxic levels of iron and aluminium content in the soil from $536 \mathrm{mg} \mathrm{kg}^{-1}$ to $161 \mathrm{mg} \mathrm{kg}^{-1}$ (Table 3 and 5).

The levels of submergence ( 5 and $10 \mathrm{~cm}$ ) and interaction between the levels of submergence and treatments showed non-significance for iron and aluminium content.

Since the $\mathrm{pH}$ of the soil increased significantly with the application of amendments and submergence the concentration of iron and aluminium showed remarkable reduction. This is in conformity with the antagonistic interaction of these ions. Tran and Vo (2004) reported that Fe may be reduced in flooded condition from $\mathrm{Fe}^{3+}$ to $\mathrm{Fe}^{2+}$ but flooding will cause increase in the soil $\mathrm{pH}$ which results in concomitant reduction of soluble Fe (Table 4).

The present study also showed that flooding causes increase in $\mathrm{pH}$ from the initial value which may result in reduction of in Fe content here the soil reduction results in conversion of $\mathrm{Fe}^{3+}$ to soluble $\mathrm{Fe}^{2+}$ forms but the enhanced $\mathrm{pH}$ reduce the flux.

Ponnamperuma and Nhung (1965) also reported that activities of water soluble $\mathrm{Al}^{3+}$ and $\mathrm{Fe}^{2+}$ decreases for each unit increase in $\mathrm{pH}$. Application of lime alone and combination of lime and phosphogypsum showed superior effect in reducing their toxic concentration in soil. Increase in $\mathrm{Ca}$ and $\mathrm{Mg}$ added through amendments also favours the reduction of toxic $\mathrm{Fe}$ and $\mathrm{Al}$. Azman et al., (2014) also reported that after the application of lime $\mathrm{Fe}$ and $\mathrm{Al}$ concentration will decline whereas $\mathrm{Ca}$ and $\mathrm{Mg}$ will increase. Phosphogypsum is a very good source of $\mathrm{Ca}$ amendment (Mrabet et al., 2003) it also alleviate the aluminium toxicity and increases plant growth (Alva and Sumner, 1989).

\section{References}

Alva, A.K., Sumner, M.E. and Miller, W.P. 1990. Reactions of gypsum or phosphogypsum in highly weathered acid subsoils. Soil Science Society of America Journal, 54(4), pp.993-998.

Azman, E. A., Jusop, S., Ishak, C. F. and Ismail, R. 2014. Increasing Rice Production Using Different Lime Sources on an Acid Sulphate Soil in Merbok, Malaysia. Pertanika J. Trop. Agric.l Sci. 37(2).

Castro, G.S.A., Crusciol, C.A.C., da Costa, C.H.M., Ferrari Neto, J. and Mancuso, M.A.C. 2016. Surface application of limestone and calcium-magnesium silicate in a tropical no-tillage system. $J$. Soil sci. Plant Nutr., 16(2), pp.362-379.

Crusciol, C.A., Artigiani, A.C., Arf, O., CarmeisFilho, A.C., Soratto, R.P., Nascente, A.S. and Alvarez, R.C., 2016. Soil fertility, plant nutrition, and grain yield of upland rice affected by surface application of lime, silicate, and phosphogypsum in a tropical no-till system. Catena, 137, pp.87-99.

Deepa K. K. 2008. Amelioration of subsoil acidity and al toxicity in laterite soils under blackpepper. M.Sc.(Ag) thesis, Kerala Agricultural University, Thrissur, $73 p$.

Fageria, N.K. and Carvalho, J.R.P., 1982. Influence of aluminum in nutrient solutions on chemical composition in upland rice cultivars. Plant and soil, 69(1), pp.31-44.

Lee, C.H., Lee, Y.B., Lee, H. and Kim, P.J., 2007. Reducing phosphorus release from paddy soils by a fly ash-gypsum mixture. Bioresource Technol. 98(10), pp.19801984.

Mrabet, R., Abril, J.M., Perianez, R., Manjon, 
G., Garcia-Tenorio, R., Delgado, A. and Andreu, L. 2003. Phosphogypsum amendment effect on radionuclide content in drainage water and marsh soils from southwestern Spain. J. Environ. quality 32(4), pp.1262-1268.

Ponnamperuma, F.N. and Nhung, M.T.M. 1965. Effects of calcium carbonate, manganese dioxide, ferric hydroxide, and prolonged flooding on chemical and electrochemical changes and growth of rice in a flooded acid sulfate soil. Soil Sci. 102(1), pp.29-41.

Shamshuddin, J., Panhwar, Q. A., Shazana, M. A. R. S., Elisa, A. A., Fauziah, C. I., and Naher, U. A. 2015. Improving the Productivity of Acid Sulphate Soils for Rice Cultivation using limestone, basalt, organic fertilizer and/or their combinations. SainsMalaysiana 45(3): 383-392.

Suswanto, T., Shamshuddin, J., Omar, S.S., Mat, P. and Teh, C.B.S. 2007. Alleviating an acid sulfate soil cultivated to rice (Oryza sativa) using ground magnesium limestone and organic fertilizer. JurnalIlmu Tanah danLingkungan, 9(1).

Tran, K.T. and T.G. Vo. 2004. Effects of mixed organic and inorganic fertilizers on rice yield and soil chemistry of the $8^{\text {th }}$ crop on heavy acid sulphate soil (Hydraquentic Sulfaquepts) in the Mekong Delta of Vietnam. 6 th Internat. Symp. Plant Soil Low pH. 1-5 August 2004, Sendai, Japan.

\section{How to cite this article:}

Ebimol, N.L., P.R. Suresh, N.K. Binitha and Santhi, G.R. 2017. Management of Iron and Aluminium Toxicity in Acid Sulphate Soils of Kuttanad. Int.J.Curr.Microbiol.App.Sci. 6(11): 1496-1503. doi: https://doi.org/10.20546/ijcmas.2017.611.177 